Article

\title{
Invasive Plant Species in the National Parks of Vietnam
}

\section{Dang Thanh Tan ${ }^{1}$, Pham Quang Thu ${ }^{1, *}$ and Bernard Dell ${ }^{2}$}

1 Vietnamese Academy of Forest Sciences, Dong Ngac, Tu Liem, Hanoi, Vietnam;

E-Mail: dangthanhtan_fsiv@yahoo.com

2 Division of Research and Development, Murdoch University, Perth, 6150, Australia;

E-Mail: b.dell@murdoch.edu.au

* Author to whom correspondence should be addressed; E-Mail: phamquangthu@fpt.vn;

Tel.: +84-913-066-586; Fax: +84-438-389-722.

Received: 12 September 2012; in revised form: 5 October 2012 / Accepted: 18 October 2012 /

Published: 30 October 2012

\begin{abstract}
The impact of invasive plant species in national parks and forests in Vietnam is undocumented and management plans have yet to be developed. Ten national parks, ranging from uncut to degraded forests located throughout Vietnam, were surveyed for invasive plant species. Transects were set up along roads, trails where local people access park areas, and also tracks through natural forest. Of 134 exotic weeds, 25 were classified as invasive species and the number of invasive species ranged from 8 to 15 per park. An assessment of the risk of invasive species was made for three national parks based on an invasive species assessment protocol. Examples of highly invasive species were Chromolaena odorata and Mimosa diplotricha in Cat Ba National Park (island evergreen secondary forest over limestone); Mimosa pigra, Panicum repens and Eichhornia crassipes in Tram Chim National Park (lowland wetland forest dominated by melaleuca); and C. odorata, Mikania micrantha and M. diplotricha in Son Tra Nature Conservation area (peninsula evergreen secondary forest). Strategies to monitor and manage invasive weeds in forests and national parks in Vietnam are outlined.
\end{abstract}

Keywords: biological invasion; exotic weeds; forests; national parks; Vietnam 


\section{Introduction}

Vietnam is a tropical country with a rich biodiversity, including 2393 non-vascular plants and 11,373 vascular plants [1]. However, of the 448 plant species listed in the Vietnam red data book, 44 species are critically endangered, 186 species are endangered and a further 213 species are vulnerable [2]. Forests provide important refugia for threatened habitats and species. The total forest area in Vietnam is nearly 13.3 million ha (39.5\% cover) [3], of which natural forest constitutes 10.3 million ha. Approximately 2.2 million ha of this is classified as special-use forest comprising 30 national parks (NP), 58 natural conservation areas (NCA), 11 species conservation areas (SCA), 45 historical forest areas (HFA) and 20 scientific forest areas (SFA). These are distributed as follows: the north-east region has $5 \mathrm{NPs}, 19 \mathrm{NCAs}, 14 \mathrm{HFAs}$ and $4 \mathrm{SCAs}$; the north-west region has $10 \mathrm{NCAs}$, 1 HFA and 2 SFA; the Red river Delta region has 4 NPs, 3 NCAs, 5 HFAs and 2 SFAs; the northern central region has $5 \mathrm{NPs}, 10 \mathrm{NCAs}, 4 \mathrm{HFAs}$ and $1 \mathrm{SFA}$; the southern central and high-land regions have 5 NPs, 15 NCAs, 8 HFAs and 5 SFAs; the south-east region has 6 NPs, 5 NCAs, 4 HFAs and 4 SFAs; and the Mekong Delta region has 5 NPs, 5 NCAs, 11 HFAs and 1 SFA [4].

According to Canh and Hai [1] the forests are under increasing pressure from disturbance. Except for some weeds of agricultural lands and waterways, for example Mimosa pigra in the Mekong delta [4,5], alien invasive plant species have received little attention in Vietnam. In the forest sector, research in this field is almost absent. In a country report on forest invasive species, Thu [6] recorded 6 invasive plant species in Vietnam. In the region, by comparison, knowledge of invasive plant species is mixed, ranging from first reports [7] to documentation and assessment of their invasive capacity [8,9]. In contrast, there are numerous studies on invasive plant species elsewhere in the world [10-12].

The terms "invasive species" was defined in the executive order 13112 of the United States in 1999 [13] and in Vietnam Biodiversity Law in 2008 [14], as "Invasive species means an alien species whose introduction does or is likely to cause economic or environmental harm or harm to human health". Other terms, such as likely invasive, potential invasive and introduction were also clarified [15-17].

Invasion by aggressive alien species causes serious problems for biodiversity, the environment, ecosystem structure and function and can impact on human health [18,19]. It is estimated that US\$1.4 trillion is the annual management cost for invasive species worldwide States [20-22]. According to Rejmanek [23], effective management of weed invasion should follow three main steps from prevention, early detection to control or eradication. This paper reports for the first time on the alien plant species that are invasive in national parks in Vietnam and thus adds to previous studies in the wider region [24]. This information is essential for foresters so they can recognize the presence of alien and invasive plant species at their park, for committees of each national park to focus their priority in protecting biodiversity, and to inform managers or policy makers within the Department of Natural Conservation (Ministry of Agriculture and Rural Development) with responsibility for producing national response strategies for invasive plants.

\section{Methods}

Representative conservation forests, ranging from mountain forests to wetland forests throughout Vietnam, were selected for surveillance. The areas investigated were: Hoang Lien NP, Cat Ba NP, 
Cuc Phuong NP, Vu Quang NP, Phong Nha-Ke Bang NP, Son Tra NCA, Chu Mom Ray NP, Cat Tien NP, U Minh Thuong NP and Tram Chim NP (in order from the north to the south of Vietnam in Figure 1).

Figure 1. Surveillance locations.

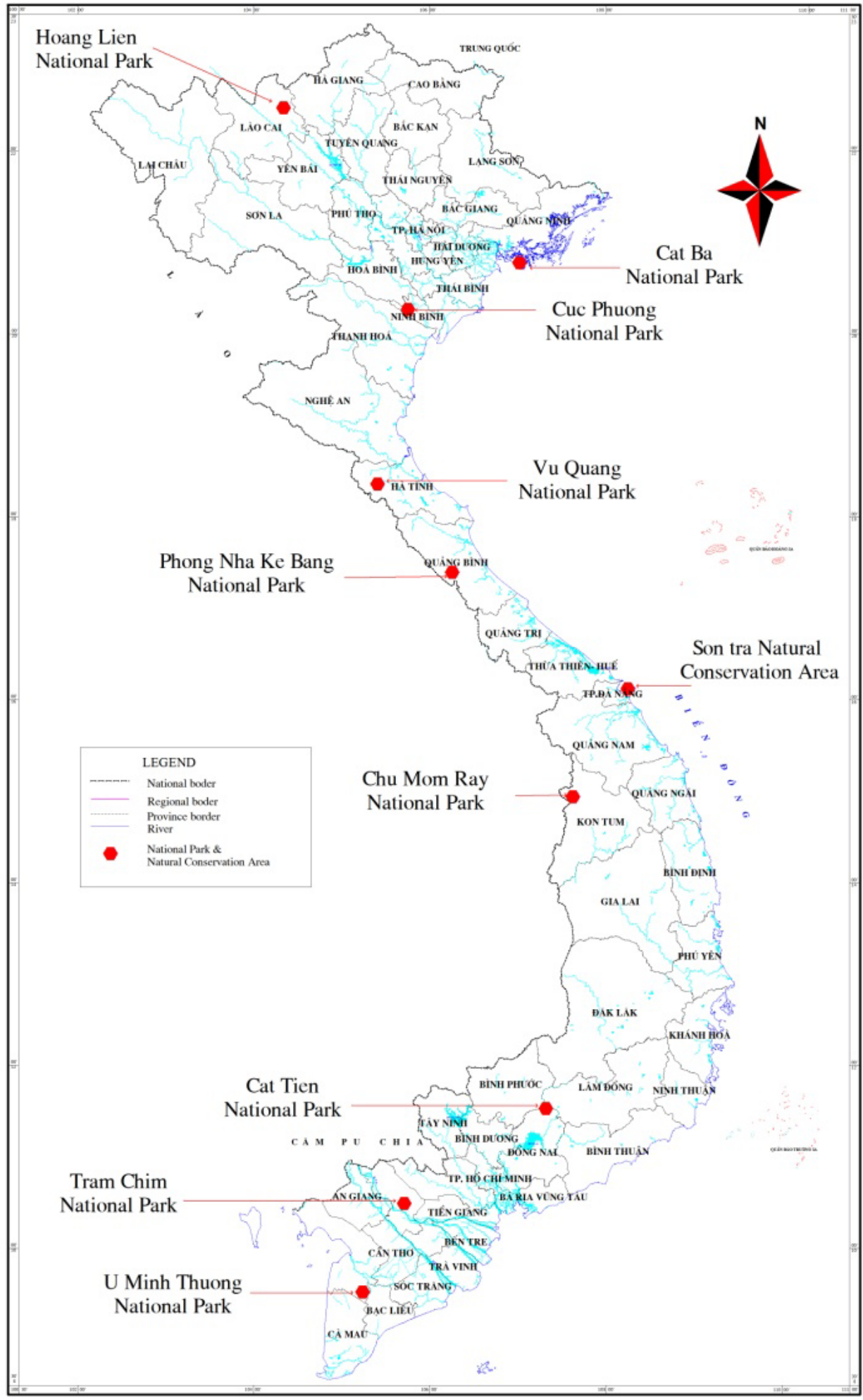


The methodology of surveillance of alien plant species was based on a protocol developed by the National Parks Service, USA [25]. Transects (3 to $12 \mathrm{~m}$ in width) were set up from April to September 2011 through forests and also along roads where local people usually access disturbed areas, and along channels and ditch sides for wetland parks. A comprehensive list of 956 non-indigenous species in Vietnam was documented based on references such as Flora of Vietnam [26-28], Vietnam Forest Trees [29,30], and Plant Species in Vietnam [31-33] as background data for field observers. For unknown weed species, herbarium specimens were collected to indentify in the laboratory. Data on habitat type, site conditions, abundance, distribution, percentage cover, and reproduction, were recorded in IPANE survey forms [34]. Species were determined to be Invasive Alien Species (IAS), Likely Invasive (L.IAS) or Potentially Invasive (P.IAS) based on criteria described by the Massachusetts Invasive Plant Advisory Group [35] and Decision \#22/2011/TT-BTNMT of the Ministry of Nature Resource and Environment, Vietnam [36].

Species listed as IAS meet the following criteria: (1) non-native in Vietnam; (2) having biological potential for rapid and widespread dispersal and establishment in minimally managed habitats, for dispersing over spatial gaps, and for existing in high number; (3) be naturalized in the parks; (4) be common in a region of habitat types or widespread in Vietnam; (5) have high number of individual forming stands in minimal managed habitats; (6) be able to out-compete other species; and (7) have the potential for rapid growth, high seed or propagule production and dissemination, and establishment in natural plant communities. Likely invasive species (L.IAS) meet first three criteria plus at least one occurrence in parks that has high individual numbers and is known to be invasive elsewhere. Potentially invasive species (P.IAS) meet first two criteria above plus pose an imminent threat to biodiversity and naturalization is anticipated.

Three study areas, Cat Ba NP, Tram Chim NP and Son Tra NCA were then chosen to assess the risk of invasive species based on published protocols [37,38]. The risks (I-Rank) were categorized into 4 classes, namely High (H), Medium (M), Low (L) and Insignificant (I).

\section{Results}

The vegetation type for the 10 parks that were surveyed is given in Table 1 . In the North of Vietnam, of 38 alien plant species at Hoang Lien NP, 6 species were invasive alien plant species (IAS) and 3 were identified as potential invasive plant species (P.IAS). At Cat Ba NP, 38 alien plant species were discovered, including 8 IAS and 7 P.IAS. In Central Vietnam, the four study areas (Cuc Phuong, Vu Quang, and Phong Nha Ke Bang national parks and Son Tra natural conservation area) had 49, 49, 45 and 53 alien plant species, respectively. The corresponding number of invasive plant and potential invasive plant species were 8 IAS and 2 P.IAS, 5 IAS and 4 P.IAS, 6 IAS and 4 P.IAS, and 5 IAS and 5P.IAS, respectively. The number of alien plant species was 52 and 65 species for Chu Mom Ray and Cat Tien NPs in the Highland region, of which there were 7 and 6 IAS, and 3 and 6 P.IAS, respectively. There was one likely invasive plant species in Cat Tien NP. For the wetland national parks in the South-western region, there were 5 IAS, 1 L.IAS and 5 P.IAS of a total of 44 alien plant species were found at Tram Chim NP whilst U Minh Thuong NP had 5 IAS and 6 P.IAS of 47 alien plant species. From this initial surveillance of invasive plant species in 10 parks in Vietnam, 134 alien plant species 
were recorded (Appendix 1), of which 25 species were invasive, likely invasive and potential invasive species (Table 1).

Table 1. Description of vegetation and the number of alien and invasive plant species for the 10 parks surveyed in Vietnam.

\begin{tabular}{|c|c|c|c|}
\hline Site & Type of vegetation & $\begin{array}{c}\text { Alien } \\
\text { plant } \\
\text { species } \\
\end{array}$ & $\begin{array}{c}\text { Invasive } \\
\text { plant } \\
\text { species } \\
\end{array}$ \\
\hline $\begin{array}{l}\text { Hoang Lien } \\
\text { NP }\end{array}$ & $\begin{array}{l}\text { The topography is divided into high mountain }(95.7 \% \text { area }) \text { and valley } \\
\text { ( } 4.3 \% \text { area). There are } 4 \text { forest types: broadleaf evergreen seasonal } \\
\text { submontane tropical forest; evergreen wet tropical forest at }<1800 \mathrm{~m} \text {; } \\
\text { mixed coniferous and broadleaf evergreen forest at } 1800-2200 \mathrm{~m} \text {; and } \\
\text { sub-tropical forest at } 2200-2600 \mathrm{~m} \text {. There are ca. } 2000 \text { plant species in } \\
200 \text { families, including valuable and rare species, such as Abies delavayi, } \\
\text { Alnus nepalensis, Calocedrus macrolepis and Taxus wallichiana. }\end{array}$ & 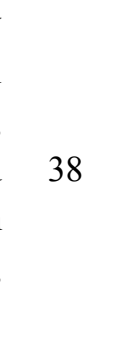 & 9 \\
\hline Cat Ba NP & $\begin{array}{l}\text { The main vegetation is evergreen tropical forest on limestone hills and } \\
\text { mountains, but it had been extensively exploited. Some areas have } \\
\text { secondary forest where shrubs are dominant. There are } 1561 \text { plant species } \\
\text { in } 149 \text { families, of which } 69 \text { are valuable and rare species such as } \\
\text { Annamocarya sinensis, Chukrasia tabularis, Pelthophorum tonkinensis } \\
\text { and Podocarpus fleurii. }\end{array}$ & s.t. & 15 \\
\hline $\begin{array}{c}\text { Cuc Phuong } \\
\text { NP }\end{array}$ & $\begin{array}{l}\text { The main type of vegetation is evergreen rain forest on limestone } \\
\text { mountains. There are } 1983 \text { plant species in } 229 \text { families, mainly } \\
\text { Acanthaceae, Asteraceae, Euphorbiaceae, Fabaceae, Lauraceae, } \\
\text { Moraceae and Rubiaceae. The park is one of the seven richest } \\
\text { biodiversity areas in Vietnam. }\end{array}$ & 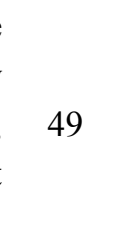 & 10 \\
\hline $\begin{array}{c}\text { Vu Quang } \\
\text { NP }\end{array}$ & $\begin{array}{l}\text { The park contains } 1612 \text { plant species in } 191 \text { families. The vegetation is } \\
\text { divided into forest types according to altitude: evergreen submontane } \\
\text { forest at } 100-300 \mathrm{~m} \text {; evergreen forest at } 300-1000 \mathrm{~m} \text {; evergreen forest at } \\
1000-1400 \mathrm{~m} \text { with dominant species in the Cupressaceae and } \\
\text { Podocarpaceae; evergreen forest at } 1400-1900 \mathrm{~m} \text { dominated by the } \\
\text { Elaeocarpaceae, Fabaceae, Lauraceae and Magnoliaceae; and evergreen } \\
\text { forest at } 1900-2200 \mathrm{~m} \text { dominated by Rhododendron and species in the } \\
\text { Elaeocarpaceae, Fagaceae and Lauraceae. }\end{array}$ & tos & 8 \\
\hline $\begin{array}{l}\text { Phong Nha } \\
\text { Ke Bang NP }\end{array}$ & $\begin{array}{l}\text { There are } 4 \text { main types of forest: closed moist evergreen forest on } \\
\text { limestone mountains dominated by Chukrasia tabularis, Dendrocnide } \\
\text { sinuata, Excentrodendron tonkinense and Fagraea fragrans; secondary } \\
\text { forest on limestone mountains dominated by Litsea cubeba, Mallotus } \\
\text { paniculatus and Rhapis cochinchinesis; stands of shrub and scattered } \\
\text { trees on limestone with dominant species such as Aporosa villosa, } \\
\text { Sapium discolor, Sterculia alata and Syzygium bonii; and closed tropical } \\
\text { moist evergreen forest on hills with Anogeissus acuminata, Dillenia } \\
\text { scabrella, Diptercarpus obtusifolius and Pometia pinnata. There are } \\
2651 \text { plant species in } 193 \text { families. }\end{array}$ & (1) & 12 \\
\hline
\end{tabular}


Table 1. Cont.

\begin{tabular}{|c|c|c|c|}
\hline Site & Type of vegetation & $\begin{array}{l}\text { Alien } \\
\text { plant } \\
\text { species }\end{array}$ & $\begin{array}{c}\text { Invasive } \\
\text { plant } \\
\text { species }\end{array}$ \\
\hline Son Tra NCA & $\begin{array}{l}\text { There are four main vegetation types: broadleaf evergreen tropical rain } \\
\text { forest dominated by species in the Dipterocarpaceae, Fagaceae, } \\
\text { Magnoliaceae, Meliaceae and Rubiaceae; secondary forest where plants } \\
\text { regenerate with the Bambusoideae; pasture land and shrub dominated by } \\
\text { Melastoma candidum, Phragmites maximus and Rhodomyrtus tomentosa; } \\
\text { and acacia and eucalypt plantations. There are } 985 \text { plant species in } \\
143 \text { families. }\end{array}$ & 53 & 12 \\
\hline $\begin{array}{c}\text { Chu Mom } \\
\text { Ray NP }\end{array}$ & $\begin{array}{l}\text { The forest is typical of the High Land region. There are } 7 \text { vegetation } \\
\text { types: closed evergreen tropical rain forest; closed evergreen subtropical } \\
\text { rain forest; dry semi-evergreen tropical forest; broadleaf woodlands of } \\
\text { dry tropical forest; secondary forest dominated by Bambusa procea and } \\
\text { Pseudoxytenanthera albo-ciliata; and grassland. There are } 1895 \text { plant } \\
\text { species in } 184 \text { families. Key families include the Dipterocarpaceae, } \\
\text { Fabaceae, Fagaceae, Lythraceae, Meliaceae, Sterculiaceae and Theaceae. }\end{array}$ & 52 & 12 \\
\hline Cat Tien NP & $\begin{array}{l}\text { The park contains flora typical of south-eastern Vietnam, and species in } \\
\text { the Dipterocarpaceae and Fabaceae are common. There are } 1615 \text { plant } \\
\text { species in } 125 \text { families, of which some are valuable and rare species such } \\
\text { as Afzelia xylocarpa, Dalbergia bariensis, D. mammos and } \\
\text { D. cochichinensis. There are } 4 \text { vegetation types: evergreen broadleaf } \\
\text { forest; semi-deciduous forest; mixed tree and bamboo forest; bamboo } \\
\text { forest; and wetland areas. }\end{array}$ & 65 & 12 \\
\hline $\begin{array}{c}\text { Tram Chim } \\
\text { NP }\end{array}$ & $\begin{array}{l}\text { The vegetation comprises a mixture of seasonally inundated grassland, } \\
\text { regenerating melaleuca forest and open swamp. Melaleuca species are } \\
\text { distributed throughout the park, both in plantations and in scattered } \\
\text { patches in areas of grassland or open swamp. There are } 130 \text { species in } \\
50 \text { families. There are five grassland communities dominated by } \\
\text { Eleocharis dulcis, E. ochrostachys, Ischaemum rugosum, Panicum } \\
\text { repens or Vossia cuspidata. }\end{array}$ & 44 & 12 \\
\hline $\begin{array}{l}\text { U Minh } \\
\text { Thuong NP }\end{array}$ & $\begin{array}{l}\text { The park contains } 243 \text { plant species in } 84 \text { families. Melaleuca forest is } \\
\text { distributed throughout the park. There are } 6 \text { habitat types: melaleuca } \\
\text { forest on waterlogged peat-land; melaleuca forest on clay soils; mixed } \\
\text { forest on peat swamp; Phragmites vallatoria grassland; open swamp; } \\
\text { Nymphaea nouchali swamp; and channels. }\end{array}$ & 47 & 12 \\
\hline \multicolumn{2}{|c|}{ Total number of species } & 134 & 25 \\
\hline
\end{tabular}

For each of the three parks where weed risks were assessed in detail, the threats of invasive species were different (Tables 2 and 3). Chromolaena odorata and Mimosa diplotricha were placed in the highest risk category at Cat Ba NP. Chromolaena odorata was widely distributed over ca. 1000 ha, occurring along roads, on barren land where trees had been felled, under disturbed forest cover, near the beach, and also on some small islands. Mimosa diplotricha was present in high numbers, sometimes climbing over other species leading to their death. At Son Tra NCA, in addition to the above two species, Mikania micrantha was also of high risk. Hundreds of hectares were invaded 
including sides of hills and forest edges. In places, M. micrantha together with a local creeper species, Operculina turpethum, smothered vegetation causing tree death.

Table 2. The risk (I-Rank) of invasive alien plant species at three parks The risks were categorized into four classes, High (H), Medium (M), Low (L) and Insignificant (I).

\begin{tabular}{|c|c|c|c|c|c|}
\hline \multirow{2}{*}{ Family } & \multirow{2}{*}{ Scientific name } & \multirow{2}{*}{ Region of origin } & \multicolumn{3}{|c|}{ I-Rank } \\
\hline & & & $\mathrm{CB}^{1}$ & $\mathbf{S T}^{2}$ & $\mathbf{T C}^{3}$ \\
\hline \multirow{4}{*}{ Asteraceae } & Ageratum conyzoides $\mathrm{L}$. & Central America & $\mathrm{L}$ & $\mathrm{L}$ & $\mathrm{L}$ \\
\hline & $\begin{array}{c}\text { Chromolaena odorata (L.) King \& H. E. } \\
\text { Robins }\end{array}$ & Central America & $\mathrm{H}$ & $\mathrm{H}$ & I \\
\hline & Mikania micrantha Kunth. & $\begin{array}{c}\text { Central and South } \\
\text { America }\end{array}$ & & $\mathrm{H}$ & \\
\hline & Parthenium hysterophorus L. & Central America & M & & \\
\hline \multirow{4}{*}{ Fabaceae } & Leucaena leucocephala (Lam.) de Wit & Tropical America & $\mathrm{L}$ & & \\
\hline & Mimosa diplotricha C. Wight ex Sauvalle & Central America & $\mathrm{H}$ & $\mathrm{H}$ & M \\
\hline & Mimosa pigra $\mathrm{L}$. & $\begin{array}{l}\text { Mexico, Central and } \\
\text { South America }\end{array}$ & $\mathrm{L}$ & M & $\mathrm{H}$ \\
\hline & Mimosa pudica $\mathrm{L}$. & Central America & $\mathrm{L}$ & $\mathrm{M}$ & $\mathrm{L}$ \\
\hline Poaceae & Eupatorium odoratum $\mathrm{L}$. & Central America & & & \\
\hline Pontedriaceae & Eichhornia crassipes (Maret.) Solms & Brazil & & & $\mathrm{H}$ \\
\hline Verbenaceae & Lantana camara $\mathrm{L}$ & Central America & $\mathrm{L}$ & $\mathrm{L}$ & \\
\hline
\end{tabular}

${ }^{1}$ Cat Ba national park; ${ }^{2}$ Son Tra natural conservation area; ${ }^{3}$ Tram Chim national park.

Mimosa pigra (Figure 2), Panicum repens and Eichhornia crassipes significantly impacted Tram Chim NP. According to a file at the Scientific Research and Environment Division of Tram Chim NP, a few small clumps appeared in 1984-1985. Ten years later M. pigra had invaded 150 ha [39], reaching 490 ha in 2000, 960 ha in 2001 and 1845 ha in 2002 (Triet pers. comm.), and ca. 2000 ha in 2009 [40]. Mimosa pigra can co-occur with other invasive species [41] including E. crassipes and P. repens, and they have invaded ca. 40 ha of Eleocharis dulci grassland. Panicum repens has now invaded $c a .8$ ha of natural inundated grasslands and about 300 ha of Oryza rufipogon grassland. Eichhornia crassipes was present in all park channels, and along with M. pigra and P. repens, has invaded 5 natural inundated grassland communities.

Figure 2. Mimosa pigra infesting Tram Chim National Park (NP).

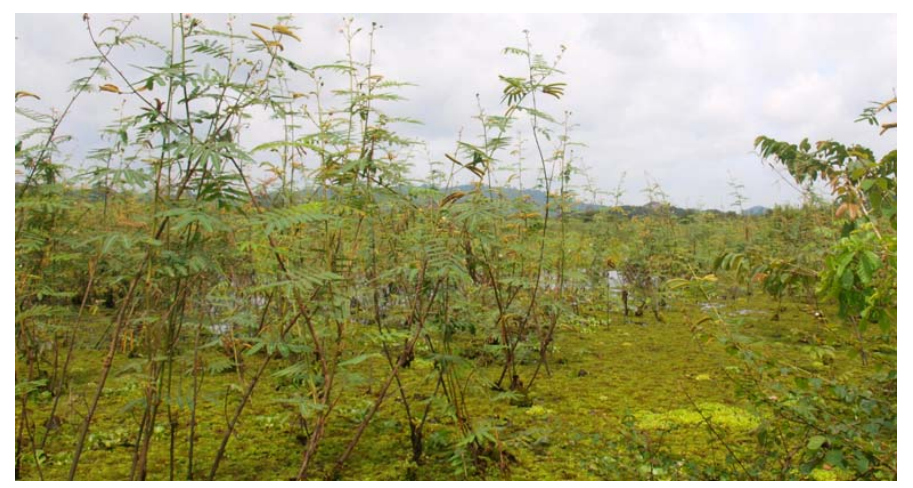


Table 3. The risk (I-Rank) of likely and potential alien plant species at three parks. The risks were categorized as in Table 2 .

\begin{tabular}{|c|c|c|c|c|c|c|}
\hline Family & Scientific name & Region of origin & Group & $\mathrm{CB}^{1}$ & $\begin{array}{l}\text { I-Ran } \\
\text { ST }^{2}\end{array}$ & $\mathrm{TC}^{3}$ \\
\hline Amaranthaceae & Amaranthus spinosus L. & Central America & P.IAS & & $\mathrm{L}$ & \\
\hline Araceae & Pistia stratiotes L. & Unknown & P.IAS & & & $\mathrm{M}$ \\
\hline & Bidens pilosa $\mathrm{L}$ & Central America & P.IAS & I & $\mathrm{M}$ & \\
\hline Asteraceae & $\begin{array}{l}\text { Xanthium strumarium DC. } \\
\text { (strumarium Auct. non L.) }\end{array}$ & Europe and America & P.IAS & $\mathrm{L}$ & & \\
\hline Cactaceae & Opuntia stricta Willem & America & P.IAS & $\mathrm{I}$ & & \\
\hline Convolvulaceae & Cuscuta chinenis Lamk. & China & P.IAS & $\mathrm{M}$ & & $\mathrm{L}$ \\
\hline Papaveraceae & Argemone mexicana $\mathrm{L}$. & $\begin{array}{l}\text { Mexico and West } \\
\text { Indies }\end{array}$ & P.IAS & & & \\
\hline Passifloraceae & Passiflora foetida $\mathrm{L}$. & Tropical America & P.IAS & $\mathrm{I}$ & & $\mathrm{M}$ \\
\hline \multirow{3}{*}{ Poaceae } & Panicum repens L. & $\begin{array}{c}\text { Tropical and North } \\
\text { Africa, Mediterranean }\end{array}$ & L.IAS & & \multirow{3}{*}{ M } & \multirow[t]{2}{*}{ M } \\
\hline & $\begin{array}{c}\text { Pennisetum polystachyon (L.) } \\
\text { Schult }\end{array}$ & Africa & L.IAS & & & \\
\hline & $\begin{array}{l}\text { Phragmites australis americanus } \\
\text { (Saltonstall, Peterson and Soreng) }\end{array}$ & North America & P.IAS & & & $\mathrm{L}$ \\
\hline Salviniaceae & Salvinia cucullata Roxb. & $\begin{array}{l}\text { India to SEA, not } \\
\text { native in Vietnam }\end{array}$ & P.IAS & & & M \\
\hline Verbenaceae & $\begin{array}{c}\text { Stachytarpheta jamaicensis (L.) } \\
\text { Vahl }\end{array}$ & $\begin{array}{c}\text { Tropical and } \\
\text { sub-tropical America }\end{array}$ & P.IAS & & $\mathrm{I}$ & \\
\hline Zingiberaceae & $\begin{array}{l}\text { Hedychium gardnerianum } \\
\text { Sheppard ex Ker Gawl }\end{array}$ & $\begin{array}{l}\text { Himalaya, India, Nepal, } \\
\text { and Bhutan }\end{array}$ & P.IAS & I & & \\
\hline
\end{tabular}

\section{Discussion}

Invasive plant species such as Chromolaena odorata, Ageratum conyzoides, Amaranthus spinosus, Bidens pilosa, Mikania micrantha and Mimosa diplotricha mainly infested disturbed areas such as in secondary forests and along walk trails in primary forests. Clearly, people as well as the biological attributes of the weeds are aiding dispersion. The numbers of alien and invasive plant species were higher in the more disturbed parks such as those in the central and high-land regions of Vietnam where over-exploitation was evident. These observations suggest that there should be restricted access to infested areas during forest rehabilitation. They further indicate the need for careful planning of tourist access ways when developing management plans for national parks. Allen et al. [42] identified a close correlation between the number of visitors and the alien weed population. It is planned that this preliminary study will lead to in depth investigation into the correlation of non-native plant species with other aspects, such as native, rare, threatened and endangered plant species; park area; elevation; roads, trials, and rivers distances; temperature; longitude; latitude; and other attributes along the lines with discussed by Allen et al. [42]. 
Alien and invasive plant species not only directly cause a decline in indigenous species, but they can alter ecosystems to such an extent that environmental harm ensues [43]. Various models have been used to described the dynamics of weed invasions [43]. For example, Macdougall and Turkington [44] used "driver" and "passenger" models to examine whether native plant richness and relative abundance affected by two dominant grasses, Poa pratensis and Dactylis glomerata, in Cowichan Garry Oak reverve, Canada. However, Didham et al. [45] pointed out three limitations of this approach because of experiment manipulation, small scale experimentation, and indirect linkage among factors. It would be useful to explore the driver, back-seat driver and passenger models for future studies in Vietnam to categorize species for priority attention and management by those authorities responsible for the forest estate.

This first list of invasive alien plant species for Vietnam highlights the need for in-country monitoring of forest weeds. In the global status of invasive forest tree species, Hayson and Murphy [46] reported on just 29 species in Asia and Vietnam was not featured. Similarly, there is little published knowledge on invasive weeds for nearby countries such as Cambodia [7] and Lao PDC [47]. Sharing of knowledge within the region will be important for managing invasive weeds, especially for those species that are widely distributed [48-50].

The invasion by two Mimosa species is causing great concern in many parts of Vietnam. In particular, M. pigra not only invades wetland areas on the sides of rivers and canals, it can infest undisturbed swamps as well as disturbed lands such as industrial tree plantations and rice fields. In addition to impacts on biota, $M$. pigra can prevent people accessing rice fields, reduces water flow in irrigation channels and keeps animals from feeding areas. For example, in Quang Nam province, in Central Vietnam, it grows spontaneously along roads and in rice fields [51], and in Thuan Bac district, Ninh Thuan province, it has invaded bare lands planned for industrial parks [52]. Warnings have been posted in Da Nang province [53,54], Hue city [55], Thac Ba lake (Yen Bai province) [56], and in the South-western region [57]. In Tri An lake, Dong Nai province, M. pigra is called the "silent killer" [58], as it now occupies some 1300 ha of the lake.

Not only is $M$. pigra now widespread in Vietnam, it is rapidly dispersed over spatial gaps away from introduction points, hence its occurrence in Cat Tien national park and Vinh Cuu nature reserve. One of the habitats in Cat Tien national park is the 3370 ha wetland that includes Bau Sau swamp (crocodile swamp), Bau Ca swamp (fish swamp), and Bau Chim swamp (bird swamp) which are connected to the Dong Nai river in the wet season. This is a Ramsar site and provides an important feeding area for migratory birds. In addition, Bau Sau is a key habitat for 50 rare IUCN-listed species including reptiles, birds, mammals and plants. The park also has significance because it is a transition zone to the last remaining lowland semi-evergreen forest in the region. Though there has been much effort to eradicate invasive weeds since 2007, they still dominate. Consequently, the feeding area for birds continues to narrow and the number of birds is decreasing (Minh Personal Communication).

A similar issue occurs at the Ramsar site in Tram Chim national park. This is one of the last remnants of the Plain of Reeds wetland ecosystems in the Mekong delta and is an important habitat for the threatened Easter Sarus Crane (Grus antigone) as well as 9 other globally threatened migratory birds. According to the Director of Tram Chim national park, the number of Easter Sarus Crane has declined with the increase in Mimosa pigra over time (Hung Personal Communication). Some 
pessimistically state that the Mekong delta will become a calamity due to invasion by M. pigra [59]. There is an urgent need to develop efficient methods to control and eradicate this alien species.

These numerous reports on invasions of $M$. pigra species are examples of the considerably negative impacts of invasive plant species, and they could rise warm attention on other species which may have similar problematic. Studies on the impacts of other invasive plant species on biodiversity, ecosystem, and event human health are also required. They will essential for foresters and committees of each national park to focus their priority in protecting biodiversity, and managers or policy makers within the Department of Natural Conservation (Ministry of Agriculture and Rural Development) with responsibility for producing national response strategies for invasive plants.

Chromolaena odorata has invaded many secondary forests from North to South-east Vietnam, and was particularly evident in Cat Ba national park and Son Tra natural conservation area. This invasive species is easily dispersed and forms dense stands. It is not known when this species was introduced to Vietnam. It appears to be having a major impact similar to that described elsewhere [60] including preventing the establishment of native species. However, a detailed assessment of the impact of this species on biodiversity and ecosystem function has yet to be carried out in Vietnam. A case study such as that undertaken in South Africa [61] should be applied in Vietnam.

A range of initiatives should be implemented to better monitor and manage invasive weeds in forests and national parks in Vietnam. Firstly, field and reference guides on the 25 invasive plant species should be produced as soon as possible using existing publications [62,63] as a guide. This will encourage forest protection and national park staff to recognize and report on invading weeds. Secondly, to minimise the introduction of new invasive species, a coordinated framework should be developed across the range of authorities responsible for the forest estate. Early detection and rapid response plans can then be developed [64]. A key aspect will be to predict the future distribution and impact of the major invasive plant species [65]. In this first project, it was not possible to survey all the different topographies and vegetation types and detailed information on populations could not be obtained. The work needs to be extended using approaches defined by Rejmánek [23].

In the national action plan on biodiversity orientation towards 2020 [66], two main tasks were identified for the control and management of alien invasive species. These are: to investigate and collect data; and to adopt and carry out strategies to prevent and control alien invasive species. The initial results of the current project provide the beginning for this plan. Much more needs to be done as the threat from invasive species for biodiversity, the environment and human health is paramount. Therefore, a national invasive weed plan for their early detection and rapid response should be implemented as has been achieved in many countries [64,67].

\section{Acknowledgments}

We are grateful to the Department of Natural Conservation, Vietnam Administration of Forest (Ministry of Agriculture and Rural Development) for project funds to allow the work to proceed. We thank our park colleagues for their kind cooperation, especially Tu (Hoang Lien NP), Hanh (Cat Ba NP), Tuan (Cuc Phuong NP), Anh (Vu Quang NP), Mui (Son Tra NCA), Dai and Tien (Chu Mom Ray NP), Hai and Minh (Cat Tien NP), Thang (U Minh Thuong Park) and Long (Tram Chim NP) who 
assisted with field surveys and provided documents on the park flora and vegetation. Thanh (RCFEE-VAFS) kindly supplied the mapping survey locations.

\section{Conflict of Interest}

We declare that this is our original piece of work and does not conflict with the interests of other individuals except where acknowledged. Contributions including professional advice and help from others are detailed in the acknowledgments.

\section{References}

1. Canh, L.X.; Hai, H.T. Status and Changes of Biodiversity in Vietnam (in Vietnamese). In The Workshop on Biodiversity; National Convention Centre: Hanoi, Vietnam, 2010.

2. Ban, N.T.; Ly, T.D.; Khoi, N.K. Vietnam Red Data Book, Part II. Plants (in Vietnamese); Natural Science and Technology Publishing: Hanoi, Vietnam, 2007; p. 611.

3. Nhi, H.D. Decision \#1828/QĐ-BNN-TCLN: Publicized Forest Status in 2010; Ministry of Agriculture and Rural Development: Hanoi, Vietnam, 2011.

4. Triet, T.; Kiet, L.C.; Thi, N.T.L.; Dan, P.Q. The Invasion of Mimosa pigra in Wetlands of the Mekong Delta, Vietnam. In Proceedings of the 3rd International Symposium on the Management of Mimosa pigra, Darwin, Australia, 22-25 September 2002; Julien, M., Flanagan, G., Heard, T., Hennecke, B., Paynter, Q., Wilson, C., Eds.; CSIRO: Canberra, Australia, 2004; pp. 45-51.

5. Triet, T.; Thi, N.T.L.; Storrs, M.J.; Kiet, L.C. The Value of Awareness and Early Intervention in the Management of Invasive Alien Species: A Case-Study on the Eradication of Mimosa pigra at the Tram Chim National Park; Secretariat of the Convention on Biological Diversity: Montreal, Canada, 2001; pp. 37-38.

6. Thu, P.Q. Forest Invasive Species and Their Impacts on Afforestation in Vietnam, The Unwelcome Guests. In Proceedings of the Asia-Pacific Forest Invasive Species Conference, Kunning, China, 17-23 August 2003; McKenzie, P., Brown, C., Jianghua, S., Jian, W., Eds.; FAO: Rome, Italy, 2003; pp. 137-141.

7. Vanna, S.; Nang, K. Cambodia-The Mimosa pigra report, The Unwelcome Guests. In Proceedings of the Asia-Pacific Forest Invasive Species Conference, Kunning, China, 17-23 August 2003; McKenzie, P., Brown, C., Jianghua, S., Jian, W., Eds.; FAO: Rome, Italy, 2003; pp. 78-79.

8. Baguinon, N.T.; Quimado, M.O.; Francisco, G.J. Country Report on Forest Invasive Species in the Philippines, The Unwelcome Guests. In Proceedings of the Asia-Pacific Forest Invasive Species Conference, Kunning, China, 17-23 August 2003; McKenzie, P., Brown, C., Jianghua, S., Jian, W., Eds.; FAO: Rome, Italy, 2003; pp. 108-113.

9. Kiapranis, R.; Nimiago, P. A Status Report on Some Invasive Forest Species in Papua New Guinea, The Unwelcome Guests. In Proceedings of the Asia-Pacific Forest Invasive Species Conference, Kunning, China, 17-23 August 2003; McKenzie, P., Brown, C., Jianghua, S., Jian, W., Eds.; FAO: Rome, Italy, 2003; pp. 102-107.

10. Handerson, L. Invasive, natrualized and causal alien plants in southern Africa: A summary based on the Southern African Plant Invaders Atlas (SAPIA). Bothalia 2007, 37, 215-248. 
11. Richardson, D.M.; Pysek, P.; Elton, C.S. 1958: The ecology of invasions by animals and plants. London: Methuen. Prog. Phys. Geogr. 2007, 31, 659-666.

12. Foxcroft, L.C.; Richardson, D.M.; Rejmánek, M.; Pysek, P. Alien plant invasions in tropical and sub-tropical savannas: Patterns, processes and prospects. Biol. Invasions 2010, 12, 3913-3933.

13. Clinton, W.J. Executive Order 13112: Invasive Species; Presidental Documents; The White House: Washington, DC, USA, 1999.

14. Nguyen, P.T. Law on Biodiversity No. 20/2008/QH12, Parliament Documents; The National Assembly, Socialist Republic of Viet Nam: Hanoi, Vietnam, 2008.

15. NISC. Invasive Species Definition Clarification and Guidance White Paper; Invasive Species Advisory Committee (ISAC): Washington, DC, USA, April 2006.

16. MIPAG. Final Report: The Evaluation of Non-Native Plant Species for Invasiveness in Massachusetts; Massachusetts Invasive Plant Advisory Group: Conway, MA, USA, 28 February, 2005.

17. Richardson, D.M.; Pysek, P.; Rejmánek, M.; Barbour, M.G.; Panetta, F.D.; West, C.J. Naturalization and invasion of alien plants: Concepts and definitions. Divers. Distrib. 2000, 6, 93-107.

18. IUCN. Alien Invasive Species: Silent Invasion (in Vietnamese); IUCN: Hanoi, Vietnam, 2003.

19. Moore, B.A. Alien Invasive Species: Impacts on Forests and Forestry; Forest Health \& Biosecurity Working Paper FBS/8E; FAO: Rome, Italy, 2005; p. 62.

20. Shimura, J. Invasive Alien Species - A Threat to Forest Diversity. In Proceedings of Asia and the Pacific Forest Health Workshop_Forest Health in a Changing World, Kuala Lumpur, 2008; HeokChoh, S., Ed.; IUFRO: Vienna, Austria, 2008; pp. 14-16.

21. Pimentel, D.; Zuniga, R.; Morrison, D. Update on the environmental and economic costs associated with alien-invasive species in the United States. Ecol. Econ. 2005, 52, 273-288.

22. Thomas, D.F. Invasive Species of Forest in the United States-2003, The Unwelcome Guests. In Proceedings of the Asia-Pacific Forest Invasive Species Conference, Kunning, China, 17-23 August 2003; McKenzie, P., Brown, C., Jianghua, S., Jian, W., Eds.; FAO: Rome, Italy; pp. 121-129.

23. Rejmánek, M. Invasive plants: Approaches and predictions. Austral Ecol. 2005, 25, 497-506.

24. Peh, K.S.-H. Invasive species in Southeast Asia: The knowledge so far. Biodivers. Conserv. 2010, 19, 1083-1099.

25. Youang, C.C.; Haack, J.L.; Morrison, L.W.; DeBacker, M.D. Invasive Exotic Plant Monitoring Protocol for Hearland Network Inventory and Monitoring Program; National Park Service: Fort Collins, CO, USA, 2007.

26. Ho, P.H. An Illustated Flora of Vietnam (in Vietnamese), 2nd ed.; Youth Publishing: Hanoi, Vietnam, 1999; Volume 1, p. 991.

27. Ho, P.H. An Illustated Flora of Vietnam (in Vietnamese), 2nd ed.; Youth Publishing: Hanoi, Vietnam, 2003; Volume 2, p. 951.

28. Ho, P.H. An Illustated Flora of Vietnam (in Vietnamese), 2nd ed.; Youth Publishing: Hanoi, Vietnam, 2003; Volume 3, p. 1020.

29. Ban, N.T.; Can, V.V.; Dung, V.V.; Khoi, N.K. Vietnam Forest Trees (in Vietnamese); Agricultural Publishing House: Hanoi, Vietnam, 2000; p. 460. 
30. Chinh, N.N.; Chung, C.T.; Can, V.V.; Dung, N.X.; Dung, V.V.; Dao, N.K.; Hop, T.; Anh, T.T.; Quynh, N.B.; Thin, N.N. Vietnam Forest Trees; Forest Inventory and Planning Institute: Hanoi, Vietnam, 2009; p. 795.

31. Ban, N.T. Checklist of Plant Species in Vietnam(in Vietnamese); Agricultural Publishing House: Hanoi, Vietnam, 2001; Volume 1, p. 1181.

32. Ban, N.T. Checklist of Plant Species in Vietnam (in Vietnamese); Agricultural Publishing House: Hanoi, Vietnam, 2003; Volume 2, p.1203.

33. Ban, N.T. Checklist of Plant Species in Vietnam (in Vietnamese); Agricultural Publishing House: Hanoi, Vietnam, 2005; Volume 3, p. 1248.

34. IPANE. Invasive Plant Atlas of New England (IPANE) Survey Form. Available online: http://www.eddmaps.org/ipane/volunteers/TerrestrialForm.pdf (accessed on 29 February 2011).

35. MIAPG. Final Report: The Evaluation of Non-Native Plant Species for Invasiveness in Massachusetts; Massachusetts Invasive Plant Advisory Group: Conway, MA, USA, 2005.

36. MONRE, Dicision \# 22/2011/TT-BTNMT. To Assign Criteria of Invasive Species and List of Invasive Species (in Vietnamese); Ministry of Nature Resource and Environment: Hanoi, Vietnam, 2011.

37. Morse, L.E.; Randall, J.M.; Benton, N.; Hieber, R.; Lu, S. An Invasive Species Assessment Protocol: Evaluating Non-Native Plants for Their Impact on Biodiversity; Version 1; NatureServe: Arlington, VA, USA, 2004; p. 40.

38. Randall, J.M.; Morse, L.E.; Benton, N.; Hiebert, R.; Lu, S.; Killeffer, T. The invasive species assessment protocol: A tool for creating regional and national lists of invasive nonnative plants that negatively impact biodiversity. Invasive Plant Sci. Manag. 2008, 1, 36-49.

39. Long, C. Tram Chim national park: An alert named "Mimosa pigra"! (in Vietnamese). Available online: http://news.socbay.com/vuon_quoc_gia_tram_chim_bao_dong_mang_ten_mai_duong_600718496-268435456.html (accessed on 21 August 2011).

40. Tri, N.V. Potential control Mimosa pigra at Tram Chim National Park by 5 Chemicals (in Vietnamese). Available online: http://www.baocantho.com.vn/index.php?mod=detnews\&catid $=63 \& \mathrm{p}=\& \mathrm{id}=44962($ accessed on 21 August 2011$)$.

41. Quoi, L.P. Report on Vegetation Mapping of Tram Trim National Park, Dong Thap Province, Vietnam; Department of Science and Technology of Long An Province: Long An, Vietnam, 2006.

42. Allen, J.A.; Brown, C.S.; Stohlgen, T.T. Non-native plant invasions of United States National Parks. Biol. Invasions 2009, 11, 2195-2207.

43. Bauer, J.T. Invasive species: "Back-seat driver" of ecosystem change? Biol. Invasions 2012, 14, 1295-1304.

44. Macdougall, A.S.; Turkington, R. Are invasive species the drivers or passengers of change in degraded ecosystems? Ecology 2005, 81, 42-55.

45. Didham, R.K.; Tylianakis, J.M.; Hutchison, M.A.; Ewers, R.M.; Gemmell, N.J. Are invasive species the drivers of ecological change? Trends Ecol. Evol. 2005, 20, 471-474.

46. Haysom, K.A.; Murphy, S.T. The Status of Invasiveness of Forest Tree Species Outside Their Natural Habitat: A Global Review and Discussion Paper; Forest Health and Biosecurity Working Paper FBS/3E; Forestry Department, FAO: Rome, Italy, 2003; p. 76. 
47. Leuangkhamma, T.; Vongsiharath, V. Forest Invasive Species in Lao PDR, The Unwelcome Guests. In Proceedings of the Asia-Pacific Forest Invasive Species Conference, Kunning, China, 17-23 August 2003; McKenzie, P., Brown, C., Jianghua, S., Jian, W., Eds.; FAO: Rome, Italy, 2003; pp. 98-99.

48. Bista, M.; Chaudhary, M. Forest Invasive Species Country Paper-Nepal, The Unwelcome Guests. In Proceedings of the Asia-Pacific Forest Invasive Species Conference, Kunning, China, 17-23 August 2003; McKenzie, P., Brown, C., Jianghua, S., Jian, W., Eds.; FAO: Rome, Italy, 2003; pp. 100-101.

49. Weerawardane, N.D.R.; Dissanayake, J. Status of Forest Invasive Species in Sri Lanka, The Unwelcome Guests. In Proceedings of the Asia-Pacific Forest Invasive Species Conference, Kunning, China, 17-23 August 2003; McKenzie, P., Brown, C., Jianghua, S., Jian, W., Eds.; FAO: Rome, Italy, 2003; pp. 114-120.

50. Murphy, S.T. Alien Weeds in Moist Forest Zones of India: Population Characteristics, Ecology and Implications for Impact and Management. In Proceedings of the Workshop on Ailen Weeds in Moist Tropical Zones, Peechi, India, 2-4 November 1999; Sankaran, K.V., Murphy, S.T., Evans, H.C., Eds.; Kerala Forest Research Insititute: Kerala, India, 2001; pp. 20-27.

51. Hoang, T. Eradication Mimosa pigra (in Vietnamese). Available online: http://www.tienphong. vn/tuong-tac/ban-doc/513046/tan-diet-ngay-cay-mai-duong.html (accessed on 21 August 2011).

52. Hoang, P.C. Eradication Mimosa pigra-A species invaded agricultural lands of Ninh Thuan province (in Vietnamese). Available online: http://www.ninhthuan.gov.vn/chinhquyen/sonnnt/ Pages/Tieu-diet-Mai-duong---loai-thuc-vat-ngoai-lai-dang-xam-chiem-vung-dat-nong-nghiep-tinh -Ninh-Thuan.aspx (accessed on 21 August 2011).

53. NhanDan, E.O. Da Nang: A critical warming of hugely apprearing Mimosa pigra at villages (in Vietnamsese). Available online: http://www.xaluan.com/modules.php?name=News\&file= article\&sid=188941 (accessed on 25 August 2011).

54. DaNang, E.O. Worries of Mimosa pigra threats (in Vietnamese). Available online: http://hn.24h. com.vn/tin-da-nang/noi-lo-tu-cay-mai-duong-c498a303806.html (accessed on 25 August 2011).

55. Toan, D. Mimosa pigra attacked Hue sity (in Vietnamese). Available online: http:// tuoitre.vn/Chinh-tri-Xa-hoi/377767/Cay-mai-duong-tan-cong-thanh-pho-Hue.html (accessed on 25 August 2011).

56. Cuong, H. Mimosa pigra species-a high risk invasive plant species (in Vietnamese). Available online: http://www.baoyenbai.com.vn/12/67251/Cay_Mai_Duong_Ke_xam_lan_nguy_hai.htm (accessed on 25 August 2011).

57. Hung, D.T.; Vinh, D. South-western region: Felt "dizzy" because of Mimosa pigra species (in Vietnamese). Available online: http://vietbao.vn/Phong-su/Mien-Tay-Nam-Bo-chong-mat-vi-caymai-duong/40036524/263/ (accessed on 25 April 2011).

58. DongNai, E.O. Mimosa pigra: "Silent killer" of Tri An Lake (in Vietnamese). Available online: http://www.dongnai.gov.vn/cong-dan/tin_khoahoc-congnghe/mlnews.2007-09-28.0245464441 (accessed on 21 August 2011).

59. Agency, V.N. Mekong delta: Mimosa pigra became crushing calamity (in Vietnamese). Available online: http://www.dichvuthuyloi.com.vn/vn/Tin-Tuc/thong-tin-ve-linh-vuc-nong-nghiep/dongbang-song-cuu-long-mai-duong-da-thanh-dai-hoa/ (accessed on 16 April 2011). 
60. Luwum, P. Control of Invasive Chromolaena odorata. An Evaluation in Some Land Use Types in KwaZulu Natal, South Africa; Internatinal Institute for Geo-Information Science and Earth Observation: Enschede, The Netherlands, 2002.

61. Wilgen, B.W.V.; Richardson, D.M.; Maitre, D.C.L.; Marais, C.; Magadlela, D. The economic consequencee of alien plant invasions: Examples of impacts and approches to sustainable management in South Africa. Environ. Dev. Sustain. 2001, 3, 145-168.

62. Huebner, C.D.; Olson, C.; Smith, H.C. Invasive Plants Field and Reference Guide: An Ecological Perpective of Plant Invaders of Forests and Woodlands; USDA Forest Service: Washington, DC, USA, 2006; Volume Supplement 1, p. 84.

63. Huebner, C.D.; Olson, C.; Smith, H.C. Invasive Plants Field and Reference Guide: An Ecological Perpective of Plant Invaders of Forests and Woodlands; USDA Forest Service: Washington, DC, USA, 2008; Volume Supplement 2, p. 36.

64. Moncrieff, A. Invasive Plant Early Detection and Rapid Response in British Columbia: An Initial Farmework. In Western Australia, Working draft Verstion 4; Department of Environment and Conservation: Perth, Australia, 2006.

65. Peterson, T. Predicting the geograohy of species' invasion via ecological niche modeling. $Q$. Rev. Biol. 2003, 78, 419-433.

66. Dung, N.T. The National Action Plan on Biodiversity up to 2010 and Orientations Towards 2020 for Implementation of the Convention on Biological Diversity and the Cartegena Protocal on Biosafety; Prime Minister Documents; Hanoi, Vietnam, 2007.

67. FICMNEW. A National Early Detection and Rapid Response System for Invasive Plants in the United States; Federal Interagency Committee for the Management of Noxious and Exotic Weeds: Washington, DC, USA, 2003; Volume Conceptual Design, p. 24. 
Appendix 1. List of alien plant species in 10 national parks in Vietnam.

\begin{tabular}{|c|c|c|c|c|c|}
\hline Family & Scientific name & $\begin{array}{c}\text { Region of } \\
\text { origin }\end{array}$ & Family & Scientific name & $\begin{array}{c}\text { Region of } \\
\text { origin }\end{array}$ \\
\hline \multirow[t]{2}{*}{ Acanthaceae } & Ruellia tuberosa L. & $\begin{array}{l}\text { Central } \\
\text { America }\end{array}$ & Asteraceae & $\begin{array}{l}\text { Sphaeranthus } \\
\text { africanus } \mathrm{L} .\end{array}$ & Africa \\
\hline & $\begin{array}{l}\text { Thunbergia } \\
\text { grandiflora (Rottl.) } \\
\text { Roxb. }\end{array}$ & Northern India & & $\begin{array}{l}\text { Sphaeranthus } \\
\text { indicus L. }\end{array}$ & India \\
\hline \multirow[t]{6}{*}{ Amaranthaceae } & $\begin{array}{l}\text { Alternanthera } \\
\text { paronichyoides } \\
\text { A. St.-Hil. }\end{array}$ & $\begin{array}{l}\text { Central } \\
\text { America }\end{array}$ & & $\begin{array}{l}\text { Synedrella } \\
\text { nodiflora }(\mathrm{L} .) \\
\text { Gaertn. }\end{array}$ & $\begin{array}{l}\text { Tropical } \\
\text { America }\end{array}$ \\
\hline & $\begin{array}{l}\text { Alternanthera sessilis } \\
\text { (L.) A. DC. }\end{array}$ & $\begin{array}{l}\text { Southern Aisa } \\
\text { or Tropical } \\
\text { America }\end{array}$ & & $\begin{array}{l}\text { Tithonia diversifolia } \\
\text { (Hemsl.) A. Gray. }\end{array}$ & $\begin{array}{l}\text { Eastern } \\
\text { Mexico and } \\
\text { Central } \\
\text { America }\end{array}$ \\
\hline & Amaranthus spinosus & Tropical & & Tridax procumbens & Tropical \\
\hline & L. & America & & L. & America \\
\hline & Celosia argentea L. & Africa & & $\begin{array}{l}\text { Xanthium } \\
\text { inaequilaterum DC. }\end{array}$ & $\begin{array}{l}\text { South Eatern } \\
\text { America, } \\
\text { Western } \\
\text { Mexio and } \\
\text { West Indies }\end{array}$ \\
\hline & $\begin{array}{l}\text { Gomphrena } \\
\text { celosioides Mart. }\end{array}$ & $\begin{array}{l}\text { Tropical } \\
\text { America }\end{array}$ & Bixaceae & Bixa orellana L. & $\begin{array}{l}\text { Tropical } \\
\text { America }\end{array}$ \\
\hline \multirow[t]{2}{*}{ Annonaceae } & Annona muricata L. & $\begin{array}{l}\text { Caribbean and } \\
\text { Central } \\
\text { America }\end{array}$ & Boraginaceae & $\begin{array}{l}\text { Heliotropium } \\
\text { indicum } \mathrm{L} .\end{array}$ & $\begin{array}{l}\text { Tropical } \\
\text { America }\end{array}$ \\
\hline & Annona reticulata $\mathrm{L}$. & $\begin{array}{l}\text { Tropical } \\
\text { America }\end{array}$ & Campanulaceae & $\begin{array}{l}\text { Sphenoclea } \\
\text { zeylanica Gaertn. }\end{array}$ & $\begin{array}{l}\text { Tropical } \\
\text { Africa }\end{array}$ \\
\hline Araceae & Pistia stratiotes L. & Unknown & Capparaceae & $\begin{array}{l}\text { Cleome } \\
\text { rutidosperma DC. }\end{array}$ & $\begin{array}{l}\text { Tropical } \\
\text { Africa }\end{array}$ \\
\hline \multirow[t]{5}{*}{ Asteraceae } & $\begin{array}{l}\text { Ageratum conyzoides } \\
\text { L. }\end{array}$ & $\begin{array}{l}\text { Central } \\
\text { America }\end{array}$ & & $\begin{array}{l}\text { Cleome spinosa } \\
\text { Jacq. }\end{array}$ & $\begin{array}{l}\text { Tropical } \\
\text { America }\end{array}$ \\
\hline & Bidens pilosa $\mathrm{L}$. & $\begin{array}{l}\text { Central } \\
\text { America }\end{array}$ & Casuarinaceae & $\begin{array}{l}\text { Casuarina } \\
\text { cunninghamiana } \\
\text { Miq. }\end{array}$ & Australia \\
\hline & $\begin{array}{l}\text { Centratherum } \\
\text { punctatum Cass. }\end{array}$ & $\begin{array}{l}\text { Tropical } \\
\text { America }\end{array}$ & Convolvulaceae & $\begin{array}{l}\text { Aniseia } \\
\text { martinicensis } \\
\text { (Jacq.) Choisy }\end{array}$ & $\begin{array}{l}\text { Tropical } \\
\text { America }\end{array}$ \\
\hline & $\begin{array}{l}\text { Chromolaena odorata } \\
\text { (L.) R. M. King \& H. } \\
\text { Rob. }\end{array}$ & $\begin{array}{l}\text { Central } \\
\text { America }\end{array}$ & & $\begin{array}{l}\text { Cuscuta chinensis } \\
\text { Lamk. }\end{array}$ & China \\
\hline & $\begin{array}{l}\text { Crassocephalum } \\
\text { crepidioides (Benth.) } \\
\text { S. Moore }\end{array}$ & Tropical Africa & & $\begin{array}{l}\text { Evolvulus } \\
\text { nummularius (L.) L. }\end{array}$ & $\begin{array}{l}\text { North \& } \\
\text { South } \\
\text { America }\end{array}$ \\
\hline
\end{tabular}


Appendix 1. Cont.

\begin{tabular}{|c|c|c|c|c|c|}
\hline Family & Scientific name & $\begin{array}{c}\text { Region of } \\
\text { origin }\end{array}$ & Family & Scientific name & $\begin{array}{c}\text { Region of } \\
\text { origin }\end{array}$ \\
\hline \multirow[t]{16}{*}{ Asteraceae } & Elephantopus mollis & West Indies & & Ipomoea hederifolia & Americas \\
\hline & Kunth. & $\begin{array}{l}\text { and Tropical } \\
\text { America }\end{array}$ & & $\mathrm{L}$ & \\
\hline & Eupatorium & Mexico & & Ipomoea quamoclit & Tropical \\
\hline & adenophorum Spreng. & & & $\mathrm{L}$ & America \\
\hline & Eupatorium odoratum & Central & & Ipomoea triloba $\mathrm{L}$. & Tropical \\
\hline & L. & America & & & America \\
\hline & Galinsoga parviflora & South & Cyperaceae & Cyperus rotundus & Eurasia \\
\hline & Cav. & America & & L. & \\
\hline & Grangea & Africa, Asia & & Cyperus & Africa and \\
\hline & maderaspatana (L.) & & & sphacelatus Rottb. & Southern \\
\hline & Poir. & & & & America \\
\hline & Mikania micrantha & Central and & & Fimbristylis & Tropical \\
\hline & Kunth. & Southern & & miliacea (L.) Vahl. & America \\
\hline & & America & & & \\
\hline & Parthenium & Central & & & \\
\hline & hysterophorus L. & America & & & \\
\hline \multirow[t]{10}{*}{ Euphorbiaceae } & Euphobia & Southern US & Fabaceae & Sesbania herbacea & Central \\
\hline & heterophylla $\mathrm{L}$. & $\begin{array}{l}\text { to Argentina } \\
\text { and West } \\
\text { Indies }\end{array}$ & & (Mill.) MacVaugh & America \\
\hline & Euphorbia hirta L. & Central & Lamiaceae & Hyptis brevipes & Central \\
\hline & & America & & Poit. & America \\
\hline & Euphorbia & Florida to & & Hyptis rhomboidea & Mexico \\
\hline & tithymaloides L. & northern & & Mart.\& Gal. & \\
\hline & & South & & & \\
\hline & & America & & & \\
\hline & Ricinus communis L. & Africa & & Hyptis suaveolens & Tropical \\
\hline & & & & (L.) Poit. & America \\
\hline \multirow[t]{8}{*}{ Fabaceae } & Acacia auriculiformis & Australia & & Leonotis nepetifolia & Tropical \\
\hline & A. Cunn. Ex Benth & & & (L.) R. Br. & Africa \\
\hline & Acacia longiflora & Australia & & Mentha arvensis L. & Europe, \\
\hline & (Andr.) Willd. & & & & $\begin{array}{l}\text { Western Asia, } \\
\text { India and } \\
\text { Nepal }\end{array}$ \\
\hline & $\begin{array}{l}\text { Acacia mangium } \\
\text { Willd. }\end{array}$ & Australia & & Mentha piperita $\mathrm{L}$. & Europe \\
\hline & Acacia saligna & Australia & Liliaceae & Asparagus plumosus & Southern \\
\hline & (Labill.) Wendl & & & Bak. & Africa \\
\hline & $\begin{array}{l}\text { Aeschvnomene } \\
\text { americana L. }\end{array}$ & $\begin{array}{l}\text { Central and } \\
\text { South } \\
\text { America }\end{array}$ & Lythraceae & $\begin{array}{l}\text { Largerstroemia } \\
\text { indica (1.) Pers. }\end{array}$ & $\begin{array}{l}\text { China, Korea } \\
\text { and Japan }\end{array}$ \\
\hline
\end{tabular}


Appendix 1. Cont.

\begin{tabular}{|c|c|c|c|c|c|}
\hline Family & Scientific name & $\begin{array}{c}\text { Region of } \\
\text { origin }\end{array}$ & Family & Scientific name & $\begin{array}{c}\text { Region of } \\
\text { origin }\end{array}$ \\
\hline \multirow[t]{16}{*}{ Fabaceae } & & & Malvaceae & $\begin{array}{l}\text { Hibiscus } \\
\text { cananbinus L. }\end{array}$ & Africa \\
\hline & Crotalaria micans & Tropical & & Hibiscus sabdariffa & Tropical \\
\hline & Link. & America & & L. & Africa \\
\hline & $\begin{array}{l}\text { Delonix regia (Hook.) } \\
\text { Raf. }\end{array}$ & Madagascar & & Sida acula Burm. f. & $\begin{array}{l}\text { Central } \\
\text { America }\end{array}$ \\
\hline & $\begin{array}{l}\text { Desmodium } \\
\text { adscendens (Sw.) DC }\end{array}$ & $\begin{array}{l}\text { Tropical } \\
\text { Africa and } \\
\text { South } \\
\text { America }\end{array}$ & & Sida rhombifolia L. & $\begin{array}{l}\text { New World } \\
\text { tropics and } \\
\text { subtropics }\end{array}$ \\
\hline & Glycyrrhiza glabra L. & $\begin{array}{l}\text { Europe - } \\
\text { Mediterranean }\end{array}$ & Marsileaceae & $\begin{array}{l}\text { Marsilea } \\
\text { quadrifolia } \mathrm{L} .\end{array}$ & $\begin{array}{l}\text { Azores and } \\
\text { Europe }\end{array}$ \\
\hline & Leucoena & Tropical & Melastomataceae & Clidemia hirta (L.) & Tropical \\
\hline & $\begin{array}{l}\text { leucocephala (Lam.) } \\
\text { deWit }\end{array}$ & America & & D. Don & America \\
\hline & $\begin{array}{l}\text { Macroptilum } \\
\text { atropurpureum (DC.) } \\
\text { Urb. }\end{array}$ & $\begin{array}{l}\text { From Texas } \\
\text { to Peru, Brazil } \\
\text { and to } \\
\text { Carribbean }\end{array}$ & Muntigiaceae & $\begin{array}{l}\text { Muntigia calabura } \\
\text { L. }\end{array}$ & $\begin{array}{l}\text { Tropical } \\
\text { America }\end{array}$ \\
\hline & $\begin{array}{l}\text { Mimosa diplotricha C. } \\
\text { Wight ex Sau valle }\end{array}$ & $\begin{array}{l}\text { Tropical } \\
\text { America }\end{array}$ & Myrtaceae & $\begin{array}{l}\text { Eucalyptus } \\
\text { camendulensis } \\
\text { Dehnh }\end{array}$ & Australia \\
\hline & Mimosa pigra $\mathrm{L}$. & $\begin{array}{l}\text { Mexico, } \\
\text { Central and } \\
\text { South } \\
\text { America }\end{array}$ & & $\begin{array}{l}\text { Eucalyptus globolus } \\
\text { Labill }\end{array}$ & Australia \\
\hline & Mimosa pudica L. & $\begin{array}{l}\text { Central } \\
\text { America }\end{array}$ & & $\begin{array}{l}\text { Eucalyptus grandis } \\
\text { Hill. Ex Maiden }\end{array}$ & Australia \\
\hline & $\begin{array}{l}\text { Pachyrhizus erosus } \\
\text { (L.) Urb. }\end{array}$ & Mexico & & $\begin{array}{l}\text { Eucalyptus robusta } \\
\text { Sm. }\end{array}$ & $\begin{array}{l}\text { Eastern } \\
\text { Australia }\end{array}$ \\
\hline & $\begin{array}{l}\text { Pithecellobium dulce } \\
\text { (Roxb.) Benth. }\end{array}$ & $\begin{array}{l}\text { Mexico, } \\
\text { Central and } \\
\text { South } \\
\text { America }\end{array}$ & Nyctaginaceae & Boerhavia erecta L. & $\begin{array}{l}\text { Central and } \\
\text { South } \\
\text { America }\end{array}$ \\
\hline & $\begin{array}{l}\text { Senna alata (L.) } \\
\text { Roxb. }\end{array}$ & Mexico & Numphaeaceae & $\begin{array}{l}\text { Victorica amazonica } \\
\text { (Poepp.) J.C. } \\
\text { Sowerby }\end{array}$ & $\begin{array}{l}\text { Tropical } \\
\text { South } \\
\text { America }\end{array}$ \\
\hline & $\begin{array}{l}\text { Senna hirsuta }(\text { L.) } \\
\text { H.S. Irwin \& Barneby } \\
\text { Senna occidentalis } \\
\text { (L.) Link. }\end{array}$ & $\begin{array}{l}\text { Tropical } \\
\text { America } \\
\text { Tropical } \\
\text { America }\end{array}$ & $\begin{array}{l}\text { Onagraceae } \\
\text { Oxalidaceae }\end{array}$ & $\begin{array}{l}\text { Ludwigia octovalis } \\
\text { Jacq. } \\
\text { Oxalis corymbosa } \\
\text { DC }\end{array}$ & $\begin{array}{l}\text { Tropical } \\
\text { America } \\
\text { Central and } \\
\text { Southern } \\
\text { America }\end{array}$ \\
\hline
\end{tabular}


Appendix 1. Cont.

\begin{tabular}{|c|c|c|c|c|c|}
\hline Family & Scientific name & $\begin{array}{c}\text { Region of } \\
\text { origin }\end{array}$ & Family & Scientific name & $\begin{array}{c}\text { Region of } \\
\text { origin }\end{array}$ \\
\hline Papaveraceae & $\begin{array}{l}\text { Argemone } \\
\text { mecicana } \mathrm{L} .\end{array}$ & $\begin{array}{l}\text { Mexico and } \\
\text { West Indies }\end{array}$ & Poaceae & $\begin{array}{l}\text { Melinis repens } \\
\text { (Willd.) Zizka }\end{array}$ & Africa \\
\hline Passifloraceae & $\begin{array}{l}\text { Passiflora } \\
\text { foetida } \mathrm{L} .\end{array}$ & $\begin{array}{l}\text { Southern } \\
\text { America }\end{array}$ & & $\begin{array}{l}\text { Panicum repens } \\
\text { L. }\end{array}$ & $\begin{array}{l}\text { Tropical and } \\
\text { North Africa, } \\
\text { Mediterranean }\end{array}$ \\
\hline Pinaceae & $\begin{array}{l}\text { Pinus caribaea } \\
\text { Morelet }\end{array}$ & $\begin{array}{l}\text { West Indies } \\
\text { and Central } \\
\text { America }\end{array}$ & & $\begin{array}{l}\text { Paspalum } \\
\text { conjugatum P. J. } \\
\text { Bergius }\end{array}$ & $\begin{array}{l}\text { Tropical } \\
\text { America }\end{array}$ \\
\hline Piperaceae & $\begin{array}{l}\text { Peperomia } \\
\text { pellucida (L.) } \\
\text { Kunth }\end{array}$ & $\begin{array}{l}\text { Tropical } \\
\text { America }\end{array}$ & & $\begin{array}{l}\text { Pennisetum } \\
\text { polystachion (L.) } \\
\text { Schult. }\end{array}$ & $\begin{array}{l}\text { Tropical } \\
\text { Africa to India }\end{array}$ \\
\hline Plantaginaceae & $\begin{array}{l}\text { Scoparia dulcis } \\
\text { L. }\end{array}$ & $\begin{array}{l}\text { Tropical } \\
\text { America }\end{array}$ & & $\begin{array}{l}\text { Pennisetum } \\
\text { purpureum } \\
\text { Schumach. }\end{array}$ & $\begin{array}{l}\text { Tropical } \\
\text { Africa }\end{array}$ \\
\hline \multirow[t]{7}{*}{ Poaceae } & $\begin{array}{l}\text { Axonopus } \\
\text { compressus } \\
\text { (Sw.) Beauv. }\end{array}$ & South America & & $\begin{array}{l}\text { Phragmites } \\
\text { australis } \\
\text { americanus } \\
\text { (Saltonstall, } \\
\text { Peterson and } \\
\text { Soreng) }\end{array}$ & $\begin{array}{l}\text { Northern } \\
\text { America }\end{array}$ \\
\hline & $\begin{array}{l}\text { Brachiaria } \\
\text { mutica (Firsk) } \\
\text { Stapf. }\end{array}$ & $\begin{array}{l}\text { Tropical Africa } \\
\text { and America }\end{array}$ & & & \\
\hline & $\begin{array}{l}\text { Cenchrus ciliaris } \\
\text { L. }\end{array}$ & $\begin{array}{l}\text { India, } \\
\text { Mediterranean, } \\
\text { Tropical and } \\
\text { Southern } \\
\text { Africa }\end{array}$ & Polygalaceae & $\begin{array}{l}\text { Polygala } \\
\text { paniculata L. }\end{array}$ & $\begin{array}{l}\text { From Mexico } \\
\text { and West } \\
\text { Indies to } \\
\text { Brazil }\end{array}$ \\
\hline & $\begin{array}{l}\text { Chloris barbata } \\
\text { Sw. }\end{array}$ & $\begin{array}{l}\text { Central and } \\
\text { South America }\end{array}$ & Pontedriaceae & $\begin{array}{l}\text { Eichhornia } \\
\text { crassipes } \\
\text { (Maret.) Solms }\end{array}$ & Brazil \\
\hline & $\begin{array}{l}\text { Cynodon } \\
\text { dactylon }(\mathrm{L} .) \\
\text { Pers }\end{array}$ & $\begin{array}{l}\text { Southern } \\
\text { Europe }\end{array}$ & Portulacaceae & $\begin{array}{l}\text { Portulaca pilosa } \\
\text { L. }\end{array}$ & Americas \\
\hline & $\begin{array}{l}\text { Dactyloctenium } \\
\text { aegyptiacum (L.) } \\
\text { Willd }\end{array}$ & Africa & & $\begin{array}{l}\text { Portulaca } \\
\text { oleracea L. }\end{array}$ & Europe \\
\hline & $\begin{array}{l}\text { Digitaria } \\
\text { longiflora } \\
\text { (Retz.) Pers. }\end{array}$ & India & Rubiaceae & $\begin{array}{l}\text { Hedyotis } \\
\text { corymbosa (L.) } \\
\text { Lamk. }\end{array}$ & $\begin{array}{l}\text { Tropical } \\
\text { Africa, } \\
\text { Madagascar } \\
\text { and India }\end{array}$ \\
\hline
\end{tabular}


Appendix 1. Cont.

\begin{tabular}{|c|c|c|c|c|c|}
\hline Family & Scientific name & $\begin{array}{c}\text { Region of } \\
\text { origin }\end{array}$ & Family & Scientific name & $\begin{array}{c}\text { Region of } \\
\text { origin }\end{array}$ \\
\hline \multirow[t]{9}{*}{ Poaceae } & $\begin{array}{l}\text { Echinochloa } \\
\text { colona (L.) Link }\end{array}$ & India & & $\begin{array}{l}\text { Spermacoce } \\
\text { exilis (L.O. } \\
\text { Williams) C. D. } \\
\text { Adams }\end{array}$ & $\begin{array}{l}\text { Africa and } \\
\text { Malesia }\end{array}$ \\
\hline & $\begin{array}{l}\text { Echinochloa } \\
\text { crusgalli (L.) P. } \\
\text { Beauv }\end{array}$ & $\begin{array}{l}\text { Subtropical and } \\
\text { temperate areas }\end{array}$ & Salviniaceae & $\begin{array}{l}\text { Salvinia } \\
\text { cucullata Roxb. }\end{array}$ & $\begin{array}{l}\text { India to SEA, } \\
\text { not native in } \\
\text { Vietnam }\end{array}$ \\
\hline & $\begin{array}{l}\text { Eleusine indica } \\
\text { (L.) Gaertn }\end{array}$ & Africa & Sapindaceae & $\begin{array}{l}\text { Cardiospermum } \\
\text { halicacabum L. }\end{array}$ & $\begin{array}{l}\text { North and } \\
\text { Tropical } \\
\text { America }\end{array}$ \\
\hline & $\begin{array}{l}\text { Eriochloa } \\
\text { polystachya } \\
\text { Kunth }\end{array}$ & $\begin{array}{l}\text { Tropical } \\
\text { America }\end{array}$ & & $\begin{array}{l}\text { Sapidus } \\
\text { saponaria L. }\end{array}$ & $\begin{array}{l}\text { Mexico and } \\
\text { South } \\
\text { America }\end{array}$ \\
\hline & $\begin{array}{l}\text { Hymenachne } \\
\text { amplexicaulis } \\
\text { (Rudge) Nees }\end{array}$ & $\begin{array}{l}\text { Central and } \\
\text { South America }\end{array}$ & Solanaceae & $\begin{array}{l}\text { Physalis } \\
\text { angulata } \mathrm{L} .\end{array}$ & $\begin{array}{l}\text { Tropical } \\
\text { America }\end{array}$ \\
\hline & Leersia & Tropical & & Solanum & North and \\
\hline & hexandra Sw. & America & & $\begin{array}{l}\text { americanum } \\
\text { Mill. }\end{array}$ & $\begin{array}{l}\text { South } \\
\text { America }\end{array}$ \\
\hline & & & Verbenaceae & $\begin{array}{l}\text { Lantana camara } \\
\text { L. }\end{array}$ & $\begin{array}{l}\text { Central } \\
\text { America }\end{array}$ \\
\hline & $\begin{array}{l}\text { Panicum } \\
\text { maximum Jacq. }\end{array}$ & Africa & & $\begin{array}{l}\text { Stachutarpheta } \\
\text { jamaicensis( L). } \\
\text { Vahl }\end{array}$ & Caribbean \\
\hline
\end{tabular}

(C) 2012 by the authors; licensee MDPI, Basel, Switzerland. This article is an open access article distributed under the terms and conditions of the Creative Commons Attribution license (http://creativecommons.org/licenses/by/3.0/) 